JPPUMA: Jurnal Ilmu Pemerintahan dan Sosial Politik UMA Uournal of Governance and Political Social

UMA), 8 (1) (2020): 1-8, DOI: https://doi.org/10.31289/ippuma.v8i1.2765

JPPUMA: Jurnal Ilmu Pemerintahan dan Sosial Politik UMA

(Journal of Governance and Political Social UMA)

Available online http://ojs.uma.ac.id/index.php/jppuma

\title{
Edy Rahmayadi and Musa Rajekshah's championing factors in Indonesia's North Sumatra Gubernatorial election in 2018
}

\author{
Mukhaira Mulia Miraza ${ }^{1}{ }^{*}$, Heri Kusmanto²) \& Warjioº $^{2}$ )
}

1) Postgraduate Program in Political Science, Faculty of Social and Political Sciences,

Universitas Sumatera Utara, Indonesia

2) Department of Political Science, Faculty of Social and Political Sciences,

Universitas Sumatera Utara, Indonesia

Recieved: August 2, 2019; Accepted: January 22, 2020; Published: May 11, 2020

\begin{abstract}
The gubernatorial election in North Sumatra has been organized in 2008. Two pairs of candidates run in the election, namely Djarot Syaiful Hidayat and Sihar Sitorus (DJOSS), and Edy Rahmayadi and Musa Rajekshah (ERAMAS). Championing the election, several issues have been used to support Edy Rahmayadi and Musa Rajekshah's victory, such as religious identity politics and the politics of locality, which exploit the identity of socalled 'son of the soil'. This study aims to understand how these factors work and determine the victory of ERAMAS. It focuses on two political means to find out which factors that contribute more significantly in the triumph of ERAMAS candidate. Using descriptive-qualitative methods, this study collects data through a questionnaire with 'SLOVIN' formula to define population and sample selected through random technique. It applies the theories of identity and political participation with a locus of the research in a purposively-selected district in Medan city, Kecamatan Medan Marelan. This research argues that there are three determining factors that contribute to the ERAMAS' victory in the Gubernatorial Election of North Sumatra in 2018, which are religious identity politics, politics of locality, and the personal influence of the candidates.
\end{abstract}

Keywords: Gubernatorial Election, Identity Politics, Political Participation

How to Cite: Miraza, M.M Kusmanto, H \& Warjio(2020). Edy Rahmayadi and Musa Rajekshah's championing factors in Indonesia's North Sumatra Gubernatorial election in 2018. JPPUMA: Jurnal Ilmu Pemerintahan dan Sosial Politik UMA (Journal of Governance and Political Social UMA), 8(1): 1-8

${ }^{*}$ Corresponding author:

ISSN 2549-1660 (Print)

E-mail: mulia1090@gmail.com

ISSN 2550-1305 (Online) 


\section{INTRODUCTION}

A general election is one of the political activities. It has been regarded as an institution and political practice at the same time, which serves to establish a legitimate governmental and public representative agencies in a democratic state. As mentioned above, in a democratic state, the general election is one of the important elements. It has been a parameter in measuring democracy indicators. The implementation of the election indicates how democratic a state is. Democracy stands a governmental system mandated by people, and for the people, which in this sense, the people hold sovereignty (Sorensen, 2003).

In Indonesia, regional autonomy in the reformasi era is in opposition to the governance system under Suharto's Orde Baru (new order). Orde Baru applied strong centralistic governance controlled by the central authority. Whereas, in the reformasi era, it has changed to a decentralized governance system (Haste, 2006). This aims to distribute equally the product of development to Indonesian regions to reduce social inequality among them. Thus, regional autonomy has been expected to become a solution over the power imbalance between the central authority and its regions, national disintegration, and to accommodate public aspiration at the local level (Kutbas, 2015).

As a political practice, the general election has undoubtedly two interrelated and interdependent functions. The election functions as tools of political legitimacy and political representative. Other functions are to become a succession mechanism to elect the ruling political elites for power, and as a means to educate people in politics (Budiardjo, 2008). In its implementation, there is a mechanism to vote candidates in local elections by the people, not represented in parliament, which has been started since 2005 (Syamsuddin, 2008).
The general election for a local leader (governor, regent, mayor) by the people as voters started in June 2005 based on Law No. 22 of 1999, which is following the amendment of the Indonesian Constitution (UUD 1945). According to the new regulations, the Indonesian President is not voted by House of Representative (Dewan Perwakilan Rakyat/DPR) but through a general election. This is also by Law No. 22 of 2003 on structure and position of Senate, House of Representative, Regional Representative and Regional Parliament (Susunan Kedudukan/Susduk MPR, DPR, DPD, dan DPRD). According to the regulation, the Regional Parliament has no competence anymore to vote for governor, regent, and mayor (gubernur/bupati/walikota). These two determining factors have initiated the idea and the necessity of public election (Herimini, 2011).

Within the process of the local election, several things can be explained related to the actual process of democracy. First, people can be involved in the arena of the public domain to promote, narrate and deliver their demands to the public and those who are interested in it. Besides, they can also be involved in demonstration or protest to the process of governmentinitiated public policy considered as not taking a side to the public interests. Second, people can target directly legislative and executive institutions, either in central or regional, to voice their aspirations, such as through a petition related to their rejection of any decision made by authorities. Third, people can be involved in the selection process of candidates for public offices through participation mechanisms (Budiardjo, 2008).

According to previous studies on the local elections in several Indonesian provinces, there are some striking points concerning the determining factors in the victory of certain candidates. An article reports about the 2010 election in the 
capital of Central Jawa, Semarang, which relates that factors that determine the triumph of a pair of candidates, namely (a) exemplary program, (b) having a career background in bureaucracy, (c) integrity, and (d) good looking (Susiatianingsih, dkk, 2011). In many provinces, municipalities, and regencies, the local election has been an interesting topic as in many regions it has been improved in its execution. At this point, people show their significance to legitimate the selection process for a political leader in their administrative region. Even though, according to a survey by the Indonesian Survey Institute (Lembaga Survei Indonesia /LSI), the competency of a candidate is the most necessary than other factors in the local election.

Except for the research on Semarang, research on an election in a new regency in North Sumatra, Batubara in 2008, uncovers that the win of the candidate is not merely imposed by the narratives of local ethnic and religious identities, but due to support from a local-oriented organization called GEMKARA (Gerakan Masyarakat Kabupaten Batubara/Batubara people movement) and because of popular candidate considered as close to the people (Lubis, 2016). It can be argued that constituents in the local election in Indonesia do not appreciate the candidates from their vision and mission (William, dkk, 2007).

According to the research mentioned above, religious identity does not become determinant. However, in the North Sumatra's Gubernatorial election in 2018, it raises my interest to conduct a study to become a topic of this article. In the 2018 election, there were two pairs of candidates running in the competition, namely Edy Rahmayadi-Musa Rajekshah (ERAMAS) with candidacy number 1 , and Djarot Syaiful Hidayat-Sihar Sitorus (DJOSS) with number 2. ERAMAS came up as the winner based on the final recapitulation of votes managed by the
General Election Commission (Komisi Pemilihan Umum/KPU Sumatra Utara).

The recapitulation reveals that ERAMAS obtained 3,291,137 votes, which is equal with 57.57 percent of the total voters. Whereas DJOSS collected 2,424,960 votes or about 42.43 percent of the total participated voters. In this election, public participation increases significantly. Conformed to KPU of North Sumatra, in the 2014 election, there are 47 percent of potential voters came to participate. While, in the 2018 election, it climbs to reach a total of 61 percent of the potential voters (KPU Provinsi Sumatera Utara, 2018).

Winning the election, ERAMAS political campaign cannot be separated from religious and ethnic identities, locality issue such as 'land of the soil' or place of origin, and a slogan 'SUMUT BERMARTABAT' (North Sumatra with dignity) which is easy to remember and preferred by the voters. Nevertheless, as a political expert in Medan Dadang Darmawan polemizes in 'tagar news' media, several factors affect the defeat of candidate No. 2 with significant difference of voters from its opponent. The most notable factor is that there is a major role of identity politics in the election. As he said, "religious identity politics still affect the Gubernatorial election in North Sumatra and ERAMAS has consistently relied on Islamic religious leader (ulama) to collect Muslim voters, which is the majority". Yet, in a democratic state, the public can participate in the political arena, at least in three different ways (Hermawan, 2019).

As requirements in the local election, every candidate has to be promoted by a minimum of 20 percent of seats in Parliament, which could be from a political party or a coalition of several parties. In 2018 election, ERAMAS has been nominated by a coalition made up by several political parties, such as Gerindra (Great Indonesia Movement), PKS (Justice and Prosperity Party), Golkar (Functional 
Groups), Nasdem (National Democrats Party), Demokrat (Democratic Party) and Hanura (People Conscience Party). All seats held by these parties form 60 percent of seats in the Parliament of North Sumatra Province. Whereas, DJOSS candidate has been nominated by PDIP (Indonesian Democratic Party of Struggle) and PPP (United Development Party), which form 20 percent of seats in the Parliament. Both sides meet the requirements to run in the election.

The gubernatorial election in North Sumatra is appealing because no incumbent governor participating in it. Both candidates (pair of the governor and deputy governor) competed in this election are Edy Rahmayadi-Musa Rajekshah (ERAMAS) and Djarot Syaiful Hidayat-Sihar Sitorus (DJOSS).

KPU Medan's recapitulation uncovers that ERAMAS won in almost all of 21 districts (kecamatan) in Medan. In Medan Marelan district, ERAMAS obtains 80 percent votes, which numbers 44,515 votes (KPU Kota Medan, 2018). Muslims form the majority of its population in five villages (kelurahan), namely Paya Pasir, Labuhan Deli, Tanah Enam Ratus, Rengas Pulau and Terjun. This creates a basic foundation for religious identity politics, which paves a way for the other factors, such as locality (son of the soil of North Sumatra) and personal influence of Edy Rahmayadi.

A gubernatorial election cannot be separated from political participation, which is voters. In common sense, political participation means personal or collective involvement in politics, particularly here in the general election, through their participation in the selection of political leaders, which can affect directly or indirectly the process of public policy. These activities include participation in the election, public rally, networking with civil society organizations, such as lobbying as one of the direct action that can be made (Budiardjo, 2008).
In a local election, politics of identity cannot be avoided and it is even still instrumentalized to boost political support. Identity politics is a configuration that can be used to define the interests of groups as a political community. Politics of identity refer to political mechanism in which an identity construction-either political or social identity-functions as political resource or tools (Setyaningrum, 2005). It exploits general identification such as religious, place of origin, ethnic or other characteristics. Therefore, identity politics is still used in the general election to drive people to vote for any candidate based on the constructed identity.

Looking at identity formation, identity construction can be grouped into three categories. First, primordialism, in which identity has been inherited, such as religion and clan. Second, constructivism, in which identity is rather created from complex social processes. Identity can be coined from cultural ties in societyfollowing the majority's favor that is regarded as a good choice. Third, instrumentalism, where identity stands as a constructed form for the sake of elites' interests. Besides, it accentuates more in the aspect of power to be achieved by candidates competing with each other through a general election. This is like tensions between groups for instance that is intentionally created by the candidates or political elites (Widayanti, 2009).

\section{RESEARCH METHOD}

This research applies a qualitative approach and a simple technique of quantitative description. The quantitative approach aims to describe a situation, which is post-factum (Ardial, 2014). In this study, the author describes a general context through statistic analysis (Sugiyono, 2012). The author limits this research to focus on the identification and analysis of determinant factors in the victory of candidate ERAMAS in North Sumatra's Gubernatorial election in 2018. 
The author collects data through questionnaire spread to the respondents, which are the sample from the population. This study defines a population as a general category including subjects and objects with certain characteristics, which can be quantified and chosen by the researcher. As a population, there are 44,515 voters in Medan Marelan district, which is chosen based on the SLOVIN formula (Prasetyo, 2005). The formula is employed to choose the sample to become respondent, which is a group with 100 respondents. They are chosen through a random sampling technique. Structured questionnaires are spread around.

\section{RESULT AND DISCUSSION}

Medan city consists of 21 kecamatan, districts, from which the author has chosen Medan Marelan as the locus of research and focuses this research to the area to bring about accurate data and reliable result. From ERAMAS' victory, it is noticeable that in Medan Marelan this candidate wins with 80 percent of total votes. Based on this achievement, this study analyzes the factors working behind the victory of the candidate. In the 2018 Gubernatorial election, there are many crucial topics in public discourse that the voters refer to decide to which candidate they give their votes. Themes that form political narratives are about religious and ethnic identity, locality or local identity (land of the soil), and issues related to the personal image of the candidate. This following discussion talks about those issues blown up in the North Sumatra Gubernatorial election.

RELIGIOUS IDENTITY. This research considers religious factors as a dominant element that backs up Edy Rahmayadi and Musa Rajekshah's win. For the voters, this factor is necessary to select a leader. It is proved that most respondents explain their reason for choosing the candidate whose the same belief with them, which is Islam. They did not vote candidates coming from a different religious backgrounds. Moreover, ERAMAS approaches people from religious affairs. The survey from the questionnaire unfolds the voters' reason in deciding to choose ERAMAS as described in the following chart.

\section{Chart 1: Respondents' reasons to choose ERAMAS}

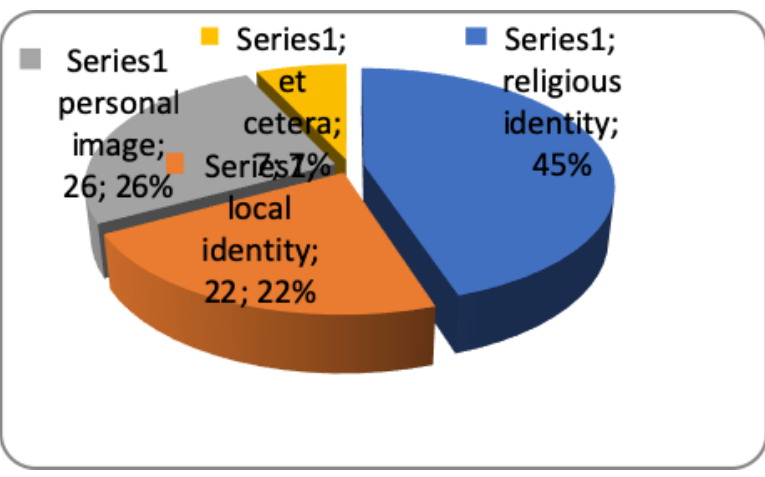

Sources: Respondents' statements, 2019

The above chart tells that most voters (45 percent of total voters) choose based on consideration of the religious identity of the candidate. People reason that they feel of obligation to choose political leaders who share a belief with them. From the ERAMAS candidate's side, the religious affair has been chosen as an approach to get close with the people. In some visits to several areas in Medan city, ERAMAS joined people to pray together in early morning prayer (subuh). Within the visits, this candidate also asked the younger generation (millennials) and other citizens to join the prayer. However, it is imaged as attempts to approach the people bringing forward brotherhood, not as a political campaign. The candidate also visited the Muslim women circle and gave a speech to win the heart of the 'mothers' group.

Despite known as a firm and decisive army general, Edy Rahmayadi performed himself as a graceful Muslim delivering a lecture during his visit. ERAMAS even invited a famous cleric Abdul Somad to attract people to attend his lecture within the candidate's visit agenda. Furthermore, 
though bringing forward the religious issue to approach the voters especially in Medan Marelan's Muslim circle (pengajian), ERAMAS is never committed to using mosque for political campaigns.

Other percentages from the chart, which is 7 percent of voters have already had a prototype of their political leaders and other reasons to choose beyond the three reasons provided in the questionnaire. Besides, another reason is due to persuasion from the team of the campaign. Newbie voters reason to choose ERAMAS due to following their parents. Looking at the educational background of voters from this area, most of them are graduated from secondary and high schools (SMP and SMA) and only a few having degrees from a university or higher education. This contributes to shaping the voters' tendency to choose a candidate who shares religious identity with them or coming from the same place of origin.

PERSONAL FIGURE. Besides religious identity, the personal image of a candidate has become the reason for voters to decide to choose ERAMAS. The above chart indicates that 26 percent of voters choose ERAMAS due to personal image. They perceive that Edy Rahmayadi is a firm and self-respected army general. The perception is built based on the physical gestures and rhetoric style that impress a prestige and fatherhood. ERAMAS often visits people but never directly persuades them to chose them.

Besides the above reasons, people choose ERAMAS due to the popularity of Edy Rahmayadi, who often visits them in Medan Marelan to build a close relationship with the people, even before his candidacy. Their people conceive Edy Rahmayadi taking care of the people and qualified as North Sumatra's governor, considered as different from the previous leaders who got sentenced to corruption scandals from Corruption Eradication Commission (KPK). This makes the emergence of Edy Rahmayadi in the political arena is imaged as a popular leader, firm as his military background and integrated. Compared to another candidate, Djarot is considered to have less capacity to manage North Sumatran society with its heterogeneity though he is experienced in leading Jakarta.

LOCAL IDENTITY. Except for the above two factors, one other factor that contributes to the triumph of ERAMAS, as shown in the above chart illustrating 22 percent of voters who chose this candidate in consideration of its place of origin, which is 'son of the soil' of North Sumatra (Putra Daerah). People regard ERAMAS coming from within North Sumatra as a necessary factor. From the other side, ERAMAS promote its originality, 'son of North Sumatra' in some official debates and claim that only son of the soil who knows well North Sumatra and can manage the region.

The above issue is felt to fit with the context of competition as the rival of ERAMAS coming from outside North Sumatra. It is the former Governor of Jakarta Djarot Syaiful Hidayat who is Javanese. Although the majority of North Sumatrans is Javanese including people living in Medan Marelan. Despite being experienced as (vice) governor, people in Marelan assume that he does not surely understand problems in North Sumatra. Let alone, he did not live in any place in the province. Further, though his counterpart Sihar Sitorus was born in North Sumatra and Batak in ethnicity, he is Christian and not a renowned figure in the local context.

From this discussion, the approach to such identities has been the main reason to vote candidate. Widayanti states that identity formation such as primordialism, in which identity is ascribed through a family connection, cannot be separated from political attitude as well. It is like constructivism configured by collective ties of society and shared perception in judging, in this case, a candidate as better than the other (Yustiningrum, 2015). In actual, respondents argue that the candidate who is originally from North 
Sumatra will understand the problems of this province and be able to solve them.

From the instrumentalist perspective, the identity has been exploited by the political elites to gain power. In the case of ERAMAS, it is clear that this candidate approaches the public from religious affairs-mass praying, visiting Muslim women circle gathering, and even involve the women in ERAMAS' team of the campaign. This approach contributes significantly to its victory in the election.

\section{CONCLUSION}

In the year 2018, almost all province or regency organized a local election, one of which is North Sumatra with a Gubernatorial election in which two pairs of candidates run in the election. Local Election Commission, KPU Sumatra Utara, announced officially that Edy Rahmayadi and Musa Rajekshah winning the election. Then, they are inaugurated as the Governor and Deputy Governor of North Sumatra for a five-year term.

Public participation went up from that of 2013 and previous elections. There are a lot of political narratives and issues during the process of a political campaign, such as religious identity, ethnicity, place of origin (so-called 'son of the soil'), and other issues including the personal figure of Edy Rahmayadi respected as a firm and authoritative.

This study reveals that several factors contribute to the victory of ERAMAS candidates, especially in Medan Marelan. Some determinant factors are its religious identity, popularity (personal and as public figure), originality or locality (place of origin). Of those factors, the most notorious one is religious identity, which became the main reason for the 45 percent of voters giving their votes to the candidate who shares a religious belief with them.

Despite two factors-religious identity and local identity-have been considered as primordial, this research found them interesting in light that there are still voters who gave their votes by considering personal popularity of candidate, which is not a primordial attitude. This could be said as the move into the maturity of political attitudes of the voters by considering no primordial attributes of a candidate. By understanding determinant factors in winning an election, a certain candidate can instrumentalize those elements to attract voters. It is still a useful way to gain public support and votes.

Except for the above factors, it is worthy to note, that the most important factor that becomes the main reason for the voters to choose a certain candidate is identity-primarily religious and social. Yet, the educational background also contributes to shaping the political attitudes of voters, which in the case of Medan Marelan, the majority graduated from junior and senior high school (SMP and SMA). Also, newbie voters follow their parents in deciding to give their votes. Eventually, it is tempting to socialize and educate people to view an election as democracy in practices to drive the political mechanism to be mature and bring prosperity to the people.

\section{BIBLIOGRAPHY}

Ardial. (2014). Paradigma dan Model Penelitian Komunikasi [Paradigm and Model of Research on Communication]. Jakarta: PT Bumi Aksara.

Budiarjo, M, (2008), Dasar-Dasar Ilmu Politik [Introduction to Political Science], Jakarta: PT. Gramedia Pustaka Utama.

Dadang Derwaman dalam https://www.tagar.id/pengamat-politikidentitas-kalahkan-djarot, di akses pada tanggal 12 Januari 2019.

Emilia Yustiningrum, RR, dan Wawan Ichwanuddin, (2015), Partisipasi Politik Dan Perilaku Memilih Pada Pemilu 2014 [Political Participation and Voters' attitude in the 2014 General Election], Jurnal Pusat Penelitian Politik, Lembaga Ilmu Pengetahuan Indonesia, 2 (1).

Harris, Syamsudin. (2008). Menggugat Pemilihan Umum Orde Baru [Challenging General Election in the New Order Indonesia]. Jakarta: Yayasan Obor Indonesia. 
Haste, H. \& Hogan, A. (2006). Beyond conventional civic participation, beyond the moralpolitical divide: Young people and contemporary debates about citizenship. Journal of Moral Education, 35(4): 473-493.

Kurtbas, I, (2015). The Factors Influencing Voting Preferences in Local Elections "An Empirical Study, International Journal of Humanities and Social Science, 5 (9): 1.

Komisi Pemilihan Umum Provinsi Sumatera Utara, 2018 tentang Rekapitulasi Suara [Recapitulation of Votes].

Liddle, R.W. \& Mujani, S. (2007). "Leadership, Party, and Religion: Explaining Voting Behavior in Indonesia". Jurnal Comparative Political Studies 40(7).

Lubis, Y.A, (2016), Faktor-faktor Penyebab Kemenangan Pasangan OK Arya Zulkarnain pada Pemilihan Kepala Deaerah Kabupaten Batubara [Determining Factors for the Winning of OK Arya Zulkarnain in the Local Election in Batubara Regency], Jurnal Politea, $8(1): 1-8$.

Prasetyo, B., \& Jannah, LM., (2005). Metode Penelitian Kuantitatif: Teori dan Aplikasi [Qualitative Research Method: Theory and Application]. Jakarta: Penerbit PT. Raja Grafindo Persada.
Setyaningrum, A. (2005). Memetakan lokasi bagi politik identitas dalam wacana politik poskolonial dalam "Politik perlawanan" [Mapping the Location of Identity Politics in Postcolonial Political Discouse in Politics of Resistance] Yogyakarta: IRE.

Sugiyono. (2012). Metode Penelitian Pendidikan Pendekatan Kuantitatif, Kualitatif, dan R\&D [Educational Reseach Method, Quantitative, Qualitative and Research and Development]. Bandung: ALFABETA. (cet. 15).

Hermini, S.F., dkk. (2011), "Faktor Determinan Kemenangan Kandidat Pada Pemilukada Kabupaten Batang 2011 [Determining Factors for the Victory of Candidate in Local Election in the Regency of Batang]".Jurnal Undip,3:1-11.

Sorensen, G. (2003). Democracy and Democratization: Processes and Prospects in a Changing World. Aarhus: Westview Press.

Widayanti, T. (2009). Politik Subaltern: Pergulatan Identitas Waria [Politics of Subaltern: Struggle of Identity of Lady-boy]. Yogyakarta: Research Center For Politics and Goverment Jurusan Politik dan Pemerintahan UGM. 